\title{
Determination of Suitable Extraction Method for the Available Iron (Fe) Content of Calcareous Soils
}

\author{
Aydın Adiloğlu' ${ }^{*}$, Sevinç Adiloğlư ${ }^{1}$, Mehmet Rüştü Karaman²
}

Department of Soil Science and Plant Nutrition, Faculty of Agriculture, Namık Kemal University, 59030 Süleymanpaşa/Tekirdağ, Turkey Department of Medical and Aromatic Plants, Sultandağ Vocational School, Afyon Kocatepe University University, 03650 Afyon, Turkey A R T I C L E I N F O A B S T R A C T

\section{Research Article}

Received 20 September 2017 Accepted 17 November 2017

Keywords.

Iron

Wheat

DTPA

Calcareous soil

Extraction method

*Corresponding Author:

E-mail: a.adiloglu@hotmail.com
The aim of this research was to determine the most suitable extraction method for the available iron contents of calcareous soils in Trakya Region, Turkey. For this purpose ten calcareous soil samples were taken from research area and five extraction methods (Lindsay and Norvell, Wear and Evans, Olson, Soltanpur and Mehlich methods) were used and three biological indices (dry matter yield, Fe concentration, Fe uptake) were compared. The plant biological indices were determined with wheat (Triticum aestivum L.) plant grown under greenhouse conditions. At the end of the experiment, the highest correlation coefficients (r) were determined between the $0.005 \mathrm{M} \mathrm{DTPA}+0.01 \mathrm{M} \mathrm{CaCl}_{2}$ $+0.1 \mathrm{M}$ TEA, $0.005 \mathrm{M}$ DTPA + $1 \mathrm{M} \mathrm{NH}_{4} \mathrm{HCO}_{3}$ methods and the biological indices. The correlation coefficients ( $r$ ) for the $0.005 \mathrm{M} \mathrm{DTPA}+0.01 \mathrm{M} \mathrm{CaCl}_{2}+0.1 \mathrm{M}$ TEA method and the three biological indices were $0.648 * *, 0.780 * *$ and $0.656 * *$ respectively. For the $0.005 \mathrm{M} \mathrm{DTPA}+1 \mathrm{M} \mathrm{NH}_{4} \mathrm{HCO}_{3}$ method, these coefficients were determined $0.595 * *$, $0.637 * *$ and $0.625 * *$, respectively. Consequently, these extraction methods were suggested for the determination of the available Fe contents of the calcareous soils in Trakya Region, Turkey.

DOI: https://doi.org/10.24925/turjaf.v6i1.51-54.1561

\section{Introduction}

The trend to more intensive crop production with higher yields and heavier use of nitrogen $(\mathrm{N})$, phosphorus $(\mathrm{P})$ and potassium $(\mathrm{K})$ fertilizers increases the need for $\mathrm{Fe}$ and other trace elements in agriculture. Soil analyses are helpful in for determining whether a soil can supply adequate amounts of $\mathrm{Fe}$ for optimal growth (Adiloğlu, 2006; Yinanç and Adiloğlu, 2017).

Iron deficiency is one of the most common trace element problems in the world nowadays. Iron deficiency is seen frequently in high $\mathrm{pH}$, high lime, and insufficient organic matter content and sandy soils (Adiloğlu, 2006; Lindsay and Schwab, 1982). Available Fe is inadequate in about $26.87 \%$ of turkey's soils and $10.4 \%$ Trakya Region (Eyüpoğu et al., 1998; Adiloğlu, 2012).

Despite the fact that several Fe extraction methods have been developed none of them was suitable to be a standard method (Loeppert and Iskeep, 1996).

Lindsay and Norvell (1978) suggested DTPA (pH: 7.3) method for the determination of available Fe content with regards to neutral and alkaline soils.

The 0.001 M EDDHA method was suggested for the determination of available $\mathrm{Fe}$ content in the USA. Because, the highest correlation coefficient was determined between this method and biological indices (Johnson and Young, 1973).
Adiloğlu (2006), has used eight extraction methods for the determination of available iron contents in Brown Forest Soils in Turkey. 0.005 M DTPA + 0.01 $\mathrm{M} \mathrm{CaCl}_{2}+$ $0.1 \mathrm{M}$ TEA and $0.005 \mathrm{M}$ DTPA $+1 \mathrm{M} \mathrm{NH} \mathrm{NHCO}_{3}$ methods were recommended by Adiloğlu for the determination of available iron contents in Brown Forest Soils in Turkey.

A research was carried out as a suitable method of the determination of available iron content of North Greece Soils. DTPA, Mehlich 3, Soltanpour and Schwab methods were suggested for North Greece Soils (Chatzistathis et al., 2014).

Krzysztof et al. (2015) have used six chemical extraction methods for the determination of available iron contents in Polish Soils. Researchers have determined the highest statistical relationships Mehlich 3 and Yanai $(0.2$ $\mathrm{M} \mathrm{CH} 3 \mathrm{COOH}+0.25 \mathrm{M} \mathrm{NH}_{4} \mathrm{Cl}+0.005 \mathrm{M} \mathrm{C}_{8} \mathrm{H}_{8} \mathrm{O}_{7}+0.05$ $\mathrm{M} \mathrm{HCl}$ ) methods. Consequently, these methods were recommended for Polish Soils by these researchers.

A research was carried out in order to find out the available iron contents and determine the most suitable extraction method of available iron contents of Oxsisols and Ultisols in Brazil. The highest correlation coefficient was determined $0.005 \mathrm{M}$ DTPA $+0.01 \mathrm{M} \mathrm{CaCl}_{2}+0.1 \mathrm{M}$ TEA and Mehlich 3 methods. Therefore, these methods were recommended by Sobral et al. (2013), as the most 
suitable methods for determination of available iron contents of Oxsisols and Ultisols in Brazil.

In this research, the most suitable method for the determination of available iron content in calcareous soils was investigated.

\section{Materials and Methods}

Soil samples were taken at $0-20 \mathrm{~cm}$ depth from 10 different cultivated calcareous soils in Trakya Region (Jackson, 1967). Soil pH (Thomas, 1996), lime (Loeppert and Suarez, 1996), organic matter amount (Nelson and Sommers, 1996) and texture (Gee and Bauder, 1986) were determined for each soil sample.

Some physical and chemical properties of the soil samples are given in Table 1. According to Table 1, pH values of soil samples ranged from 7.43 to $8.02, \mathrm{CaCO}_{3}$ contents were between $5.69 \%$ and $17.23 \%$, organic matter amounts were between $0.23 \%$ and $1.02 \%$, texture of soils samples were $(\mathrm{C})$, generally.

The available $\mathrm{Fe}$ contents of the soil samples were determined through five different chemical extraction methods. These methods are 0.005 M DTPA + 0.01M $\mathrm{CaCl}_{2}+0.1 \mathrm{M}$ TEA (Lindsay and Norvell, 1978), $0.05 \mathrm{M}$ $\mathrm{HCl}+0.012 \mathrm{M} \mathrm{H}_{2} \mathrm{SO}_{4}$ (Wear and Evans, 1968), $1 \mathrm{M}$ $\mathrm{NH}_{4} \mathrm{OAc}$ (Olson, 1948), $0.005 \mathrm{M}$ DTPA + $1 \mathrm{M} \mathrm{NH}_{4} \mathrm{OAc}$ (Soltanpur, 1991) and $0.2 \mathrm{M} \mathrm{CH} \mathrm{CH}_{3} \mathrm{COOH}+0.25 \mathrm{M}$ $\mathrm{NH}_{4} \mathrm{NO}_{3}+0.013 \mathrm{M} \mathrm{HNO}_{3}+0.015 \mathrm{M} \mathrm{NH} 4 \mathrm{~F}+0.001 \mathrm{M}$ EDTA (Mehlich, 1984). Some properties of these extraction methods are given in Table 2.

Table 1 Some physical and chemical properties of the soil samples

\begin{tabular}{|c|c|c|c|c|c|c|c|}
\hline $\begin{array}{l}\text { Soil } \\
\text { No }\end{array}$ & $\begin{array}{c}\mathrm{pH} \\
(1: 2.5)\end{array}$ & $\begin{array}{c}\mathrm{CaCO}_{3}, \\
\%\end{array}$ & $\begin{array}{c}\text { Org. matter } \\
\%\end{array}$ & $\begin{array}{c}\text { Clay } \\
\%\end{array}$ & $\begin{array}{l}\text { Silt } \\
\%\end{array}$ & $\begin{array}{c}\text { Sand } \\
\%\end{array}$ & $\begin{array}{c}\text { Texture } \\
\text { Class }\end{array}$ \\
\hline 1 & 7.66 & 12.20 & 0.52 & 38.42 & 27.66 & 33.92 & $\mathrm{CL}$ \\
\hline 2 & 7.97 & 8.58 & 0.76 & 35.23 & 25.61 & 39.16 & CL \\
\hline 3 & 7.85 & 5.69 & 0.23 & 40.42 & 15.78 & 40.80 & $\mathrm{C}$ \\
\hline 4 & 8.02 & 13.27 & 0.78 & 42.45 & 30.07 & 27.08 & $\mathrm{C}$ \\
\hline 5 & 7.62 & 17.23 & 0.67 & 38.85 & 12.10 & 49.05 & $\mathrm{SC}$ \\
\hline 6 & 7.98 & 16.52 & 0.98 & 41.08 & 33.10 & 25.82 & $\mathrm{C}$ \\
\hline 7 & 7.80 & 7.98 & 0.76 & 38.33 & 18.85 & 42.82 & $\mathrm{SC}$ \\
\hline 8 & 7.65 & 9.52 & 0.53 & 44.32 & 28.05 & 27.63 & $\mathrm{C}$ \\
\hline 9 & 7.52 & 6.67 & 1.02 & 43.28 & 24.30 & 32.42 & $\mathrm{C}$ \\
\hline 10 & 7.43 & 7.86 & 0.87 & 47.60 & 21.72 & 35.68 & $\mathrm{C}$ \\
\hline
\end{tabular}

Table 2 Chemical extraction methods were used for the determination of available Fe contents of the soil samples.

\begin{tabular}{|c|c|c|c|}
\hline Methods & $\begin{array}{l}\text { Soil }- \text { solution } \\
\text { ratio }\end{array}$ & $\begin{array}{l}\text { Shaking } \\
\text { time }\end{array}$ & Reference \\
\hline $0.005 \mathrm{M} \mathrm{DTPA}+0.01 \mathrm{M} \mathrm{CaCl}_{2}+0.1 \mathrm{M}$ TEA & $1: 2$ & 120 minutes & (Lindsay and Norvell, 1978) \\
\hline $0.05 \mathrm{M} \mathrm{HCl}+0.012 \mathrm{M} \mathrm{H}_{2} \mathrm{SO}_{4}$ & 1: 4 & 15 minutes & (Wear and Evans, 1968) \\
\hline $1 \mathrm{M} \mathrm{NH}_{4} \mathrm{OAc}$ & $1: 4$ & 30 minutes & (Olson, 1948) \\
\hline $0.005 \mathrm{M} \mathrm{DTPA}+1 \mathrm{M} \mathrm{NH}_{4} \mathrm{HCO}_{3}$ & $1: 2$ & 15 minutes & (Soltanpur, 1991) \\
\hline $\begin{array}{l}0.2 \mathrm{M} \mathrm{CH}_{3} \mathrm{COOH}+0.25 \mathrm{M} \mathrm{NH}_{4} \mathrm{NO}_{3}+0.013 \mathrm{M} \\
\mathrm{HNO}_{3}+0.015 \mathrm{M} \mathrm{NH} \mathrm{H}_{4} \mathrm{~F}+0.001 \mathrm{M} \text { EDTA }\end{array}$ & 1: 10 & 5 minutes & (Mehlich, 1984) \\
\hline
\end{tabular}

A greenhouse experiment was designed in a randomized complete block replicated three times. Air dried $2.5 \mathrm{~kg}$ soil was filled into plastic pots. Rumeli variety wheat (Triticum aestvium L.) was used as a test plant because it is sensitive to Fe deficiency (Martens and Westermann, 1991). Each pot was fertilized with $150 \mathrm{mg}$ $\mathrm{kg}^{-1} \mathrm{~N}\left(\mathrm{NH}_{4} \mathrm{NO}_{3}\right)$ and $100 \mathrm{mg} \mathrm{kg} \mathrm{P}_{2} \mathrm{O}_{5}\left(\mathrm{KH}_{2} \mathrm{PO}_{4}\right)$, according to average application rates of $\mathrm{N}$ and $\mathrm{P}_{2} \mathrm{O}_{5}$ to wheat in this region. Three different rates of $\mathrm{Fe}\left(\mathrm{Fe}_{0}: 0\right.$; $\mathrm{Fe}_{1}: 15$; and $\mathrm{Fe}_{2}: 30 \mathrm{mg} \mathrm{kg} \mathrm{kg}^{-1}$ ) were applied to soils as $\mathrm{FeSO}_{4}$ compound. Twenty plants were left in each pot after the germination. The water content of the pots was adjusted to $80 \%$ of field capacity during the experiment period. Wheat shoots were harvested after 60 days. Harvested shoots were washed once tap water and twice distilled water and dried at $65^{\circ} \mathrm{C}$. Dry matter yields were determined (Kacar and İnal, 2010).

Dried and ground plant materials were digested using $\mathrm{HNO}_{3}+\mathrm{HclO}_{4}$ and $\mathrm{Fe}$ content of plants were determined with ICP-OES (Kacar and İnal, 2010). Dry matter yield, $\mathrm{Fe}$ concentration and $\mathrm{Fe}$ uptake biological indices were used as biological method.

Correlation coefficients (r) were measured between available $\mathrm{Fe}$ content of the soils according to five different methods and biological indices (dry matter yield, $\mathrm{Fe}$ content and $\mathrm{Fe}$ uptake) of wheat plants. Significance of the correlation coefficients (r) was checked at the 1 and 5\% levels (Düzgüneş et al., 1987).

\section{Results and Discussion}

The Effects of Increasing Iron Application Rates

Dry matter yield of the wheat plants was affected by the Fe application. The highest dry matter yield was obtained from the $\mathrm{Fe}_{2}\left(30 \mathrm{mg} \mathrm{kg}^{-1}\right)$. On the other hand, $\mathrm{Fe}$ concentration and $\mathrm{Fe}$ uptake of the plants increased with increasing $\mathrm{Fe}$ application (Table 3 ). The reason of this result may be positive effect of iron application to high $\mathrm{pH}$ value and high lime contents of the soil samples. 
According to Table 3, dry matter yield of plants were determined between 2.22 and $3.18 \mathrm{mg} \mathrm{kg}^{-1}$, Fe concentration of plants were determined between 92 and $147 \mathrm{mg} \mathrm{kg}^{-1}$, and uptake of iron were determined between 226 ile $433 \mu \mathrm{g} \mathrm{pot}^{-1}$.

The effect of Fe application on the biological indices of the wheat plants was determined to be significant at 1 $\%$ level and the results obtained are in agreement with earlier reports (Başar and Özgümüş, 1999; Adiloğlu, 2006).

\section{The Available Iron Contents of Soils}

Five extraction methods were used for the determination of available Fe content of the soil samples (Table 4). Available Fe varied widely depending on the extraction method used, reasons for which could be pointed out as the type, concentration, $\mathrm{pH}$, shaking time, soil solution ratio of the extraction solution and variability observed in the physical and chemical properties of the soils used.

As shown in Table 4, the highest available Fe content of soil samples were determined with $0.005 \mathrm{M} \mathrm{DTPA}+$ $0.01 \mathrm{M} \mathrm{CaCl}_{2}+0.1 \mathrm{M}$ TEA; $0.005 \mathrm{M} \mathrm{DTPA}+1 \mathrm{M}$ $\mathrm{NH}_{4} \mathrm{HCO}_{3}$ method in comparison to other extraction methods. On the other hand, the lowest available $\mathrm{Fe}$ content of soil samples were determined with $1 \mathrm{M}$ $\mathrm{NH}_{4} \mathrm{Oac}$ and $0.05 \mathrm{M} \mathrm{HCl}+0.012 \mathrm{M} \mathrm{H}_{2} \mathrm{SO}_{4}$ methods. These results also show that higher available $\mathrm{Fe}$ was determined using methods with chelate + salt $(0.005 \mathrm{M}$ DTPA + $0.01 \mathrm{M} \mathrm{CaCl}_{2}+0.1 \mathrm{M}$ TEA) method in comparison to the methods using salt (1 $\mathrm{M} \mathrm{NH} \mathrm{NHAc}_{4}$ method) and acid $\left(0.05 \mathrm{M} \mathrm{HCl}+0.012 \mathrm{M} \mathrm{H}_{2} \mathrm{SO}_{4}\right.$ method).
The acid and salt methods of $\mathrm{HCl}+\mathrm{H}_{2} \mathrm{SO}_{4}, \mathrm{MgCl}_{2}$ and $\mathrm{NH}_{4} \mathrm{OAc}$, which gave lowest available $\mathrm{Fe}$, are not recommended for the determination of $\mathrm{Fe}$ content in neutral and alkaline soils. The use of chelate and chelate + salt methods are suggested in these types of soils (Adiloğlu, 2006).

\section{The Relationships}

The correlation coefficients ( $r$ ) determined between chemical extraction methods and biological indices are given in Table 5. Significant correlation coefficients were observed between all chemical extraction methods, except $1 \mathrm{M} \mathrm{NH} 4 \mathrm{OAc}$ method and the biological indices (dry matter yield, Fe content and Fe uptake) at $1 \%$ and $5 \%$ levels (Table 5). According to Table 5, the highest correlation coefficients ( $\mathrm{r}$ ) were determined between $0.005 \mathrm{M}$ DTPA + 0.01 $\mathrm{M} \mathrm{CaCl}_{2}+0.1 \mathrm{M}$ TEA and 0.005 $\mathrm{M}$ DTPA $+1 \mathrm{M} \mathrm{NH} \mathrm{NCO}_{3}$ methods and biological indices. These correlation coefficients (r) determined were $0.648 * *, 0.780 * *$ and $0.656^{* *}$ for $0.005 \mathrm{M} \mathrm{DTPA}+$ $0.01 \mathrm{M} \mathrm{CaCl}_{2}+0.1$ TEA method and $0.595 * *, 0.637 * *$

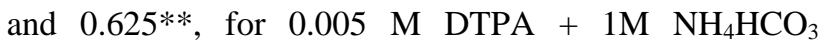
method, respectively. The lowest correlation coefficient (r) was determined with $1 \mathrm{M} \mathrm{NH} \mathrm{NHAc}_{4} \mathrm{O}$ method. These correlation coefficient were $0.310,0.296$ and $0.340 *$ with biological indices, respectively.

According to the results the order of significance for the extraction methods are as follows: $0.005 \mathrm{M} \mathrm{DTPA}+$ $0.01 \mathrm{M} \mathrm{CaCl}_{2}+0.1 \mathrm{M} \mathrm{TEA}>0.005 \mathrm{M} \mathrm{DTPA}+1 \mathrm{M}$ $\mathrm{NH}_{4} \mathrm{HCO}_{3}>0.2 \mathrm{M} \mathrm{CH} \mathrm{COOH}_{3} \mathrm{CO} 0.25 \mathrm{M} \mathrm{NH}_{4} \mathrm{NO}_{3}+$ $0.013 \mathrm{M} \mathrm{HNO}_{3}+0.015 \mathrm{M} \mathrm{NH}_{4} \mathrm{~F}+0.001 \mathrm{M}$ EDTA $>0.05$ $\mathrm{M} \mathrm{HCl}+0.012 \mathrm{M} \mathrm{H}_{2} \mathrm{SO}_{4}>1 \mathrm{M} \mathrm{NH}_{4} \mathrm{OAc}$.

Table 3 The effect of iron application on biological indices of wheat plant****

\begin{tabular}{|c|c|c|c|c|c|c|c|c|c|}
\hline \multirow{2}{*}{$\begin{array}{c}\text { Soil } \\
\text { No }\end{array}$} & \multicolumn{3}{|c|}{ Dry matter yield, $\mathrm{g}_{\text {pot }}{ }^{-1}$} & \multicolumn{3}{|c|}{ Fe concentration of plant, $\mathrm{mg} \mathrm{kg}^{-1}$} & \multicolumn{3}{|c|}{ Uptake of Fe by shoots, $\mu \mathrm{g}$ pot $^{-1}$} \\
\hline & $\mathrm{Fe}_{0}$ & $\mathrm{Fe}_{1}$ & $\mathrm{Fe}_{2}$ & $\mathrm{Fe}_{0}$ & $\mathrm{Fe}_{1}$ & $\mathrm{Fe}_{2}$ & $\mathrm{Fe}_{0}$ & $\mathrm{Fe}_{1}$ & $\mathrm{Fe}_{2}$ \\
\hline 1 & $2.46^{\mathrm{a}}$ & $2.78^{b}$ & $2.96^{\mathrm{c}}$ & $92^{\mathrm{a}}$ & $112^{b}$ & $123^{\mathrm{c}}$ & $226^{\mathrm{a}}$ & $311^{b}$ & $364^{\mathrm{c}}$ \\
\hline 2 & $2.38^{\mathrm{a}}$ & $2.63^{b}$ & $2.87^{\mathrm{c}}$ & $102^{\mathrm{a}}$ & $115^{b}$ & $126^{\mathrm{c}}$ & $243^{\mathrm{a}}$ & $302^{b}$ & $362^{c}$ \\
\hline 3 & $2.22^{\mathrm{a}}$ & $2.46^{\mathrm{b}}$ & $2.69^{c}$ & $110^{\mathrm{a}}$ & $121^{\mathrm{b}}$ & $138^{\mathrm{c}}$ & $244^{\mathrm{a}}$ & $298^{b}$ & $371^{\mathrm{c}}$ \\
\hline 4 & $2.35^{\mathrm{a}}$ & $2.70^{b}$ & $2.93^{\mathrm{c}}$ & $98^{\mathrm{a}}$ & $110^{b}$ & $120^{\mathrm{c}}$ & $230^{\mathrm{a}}$ & $297^{b}$ & $351^{c}$ \\
\hline 5 & $2.53^{\mathrm{a}}$ & $2.86^{b}$ & $3.12^{\mathrm{c}}$ & $112^{\mathrm{a}}$ & $127^{b}$ & $138^{c}$ & $283^{a}$ & $363^{b}$ & $431^{c}$ \\
\hline 6 & $2.46^{\mathrm{a}}$ & $2.85^{b}$ & $3.14^{\mathrm{c}}$ & $102^{\mathrm{a}}$ & $118^{b}$ & $132^{\mathrm{c}}$ & $251^{\mathrm{a}}$ & $336^{b}$ & $415^{c}$ \\
\hline 7 & $2.52^{\mathrm{a}}$ & $2.83^{b}$ & $3.18^{\mathrm{c}}$ & $108^{a}$ & $128^{b}$ & $136^{c}$ & $272^{\mathrm{a}}$ & $362^{b}$ & $433^{c}$ \\
\hline 8 & $2.51^{\mathrm{a}}$ & $2.74^{b}$ & $3.05^{\mathrm{c}}$ & $102^{\mathrm{a}}$ & $128^{b}$ & $137^{\mathrm{c}}$ & $256^{\mathrm{a}}$ & $351^{\mathrm{b}}$ & $418^{c}$ \\
\hline 9 & $2.42^{\mathrm{a}}$ & $2.65^{b}$ & $2.89^{\mathrm{c}}$ & $110^{a}$ & $135^{b}$ & $147^{\mathrm{c}}$ & $266^{\mathrm{a}}$ & $358^{b}$ & $425^{c}$ \\
\hline 10 & $2.45^{\mathrm{a}}$ & $2.78^{b}$ & $3.02^{\mathrm{c}}$ & $110^{a}$ & $130^{b}$ & $146^{c}$ & $270^{\mathrm{a}}$ & $361^{b}$ & $393^{c}$ \\
\hline
\end{tabular}

*: Values of three replication average, $* *$ : Each biological indices was evaluated individually.

Table 4 Iron content in soils determined by different chemical extraction methods

\begin{tabular}{|c|c|c|c|c|c|c|c|c|c|c|}
\hline \multirow{2}{*}{ Method } & \multicolumn{10}{|c|}{ Available Fe content, $\mathrm{mg} \mathrm{kg}^{-1}$} \\
\hline & 1 & 2 & 3 & 4 & 5 & 6 & 7 & 8 & 9 & 10 \\
\hline $\begin{array}{l}0.005 \mathrm{M} \mathrm{DTPA}+0.01 \mathrm{M} \mathrm{CaCl}_{2}+0.1 \mathrm{M} \\
\text { TEA }\end{array}$ & 4.78 & 5.52 & 3.24 & 7.86 & 4.45 & 6.53 & 2.12 & 5.07 & 3.19 & 6.32 \\
\hline $0.05 \mathrm{M} \mathrm{HCl}+0.012 \mathrm{M} \mathrm{H}_{2} \mathrm{SO}_{4}$ & 2.30 & 2.24 & 1.15 & 3.47 & 1.08 & 4.74 & 1.16 & 2.61 & 1.87 & 2.42 \\
\hline $1 \mathrm{M} \mathrm{NH}_{4} \mathrm{OAc}$ & 2.12 & 1.89 & 1.02 & 3.41 & 2.16 & 2.87 & 0.56 & 3.21 & 1.16 & 2.45 \\
\hline $\begin{array}{l}0.005 \mathrm{M} \mathrm{DTPA}+1 \mathrm{M} \mathrm{NH}_{4} \mathrm{HCO}_{3} \\
0.2 \mathrm{M} \mathrm{CH}_{3} \mathrm{COOH}+0.25 \mathrm{M} \mathrm{NH}_{4} \mathrm{NO}_{3}+\end{array}$ & 4.42 & 4.89 & 2.76 & 5.41 & 3.20 & 4.98 & 1.46 & 4.24 & 2.62 & 5.27 \\
\hline $\begin{array}{l}0.013 \mathrm{M} \mathrm{HNO}_{3}+0.015 \mathrm{M} \mathrm{NH}_{4} \mathrm{~F}+0.001 \\
\text { M EDTA }\end{array}$ & 3.46 & 2.96 & 4.21 & 6.85 & 4.27 & 4.87 & 1.02 & 3.64 & 3.04 & 5.12 \\
\hline
\end{tabular}


Table 5 The correlation coefficients ( $\mathrm{r}$ ) were between chemical extraction methods and biological indices

\begin{tabular}{|c|c|c|c|}
\hline \multirow[b]{2}{*}{ Chemical extraction methods } & \multicolumn{3}{|c|}{ Non application of $\mathrm{Fe}$ in pots $\left(\mathrm{Fe}_{0}\right)$} \\
\hline & $\begin{array}{l}\text { Dry matter } \\
\text { yield }\end{array}$ & $\begin{array}{l}\text { Fe concentration } \\
\text { of plant }\end{array}$ & $\begin{array}{l}\text { Uptake of Fe } \\
\text { amount from soil }\end{array}$ \\
\hline $0.005 \mathrm{M} \mathrm{DTPA}+0.01 \mathrm{M} \mathrm{CaCl}_{2}+0.1 \mathrm{M}$ TEA & $0.648 * *$ & $0.780 * *$ & $0.656^{* *}$ \\
\hline $0.05 \mathrm{M} \mathrm{HCl}+0.012 \mathrm{M} \mathrm{H}_{2} \mathrm{SO}_{4}$ & $0.378 *$ & $0.421 *$ & $0.385^{*}$ \\
\hline $1 \mathrm{M} \mathrm{NH}_{4} \mathrm{OAc}$ & 0.310 & 0.296 & $0.340 *$ \\
\hline $0.005 \mathrm{M} \mathrm{DTPA}+1 \mathrm{M} \mathrm{NH}_{4} \mathrm{HCO}_{3}$ & $0.595 * *$ & $0.637 * *$ & $0.625 * *$ \\
\hline $\begin{array}{l}0.2 \mathrm{M} \mathrm{CH}_{3} \mathrm{COOH}+0.25 \mathrm{M} \mathrm{NH}_{4} \mathrm{NO}_{3}+0.013 \mathrm{M} \mathrm{HNO}_{3}+ \\
0.015 \mathrm{M} \mathrm{NH}_{4} \mathrm{~F}+0.001 \mathrm{M} \text { EDTA }\end{array}$ & $0.578 * *$ & $0.460 * *$ & $0.526 * *$ \\
\hline
\end{tabular}

\section{Conclusion}

According to the this research results, $0.005 \mathrm{M}$ DTPA $+0.01 \mathrm{M} \mathrm{CaCl}_{2}+0.1 \mathrm{M}$ TEA and $0.005 \mathrm{M} \mathrm{DTPA}+1 \mathrm{M}$ $\mathrm{NH}_{4} \mathrm{HCO}_{3}$ methods, can be used confidently to determine the available Fe content of the calcareous soils of Trakya region because the highest correlation coefficients $(r)$ were determined when these methods were used (Table 5). These methods were also suggested for various regional soils (Aydemir, 1981; Haddad and Evans, 1993; Adiloğlu, 2006).

Consequently all of the following methods i.e. 0.005 $\mathrm{M} \mathrm{DTPA}+0.01 \mathrm{M} \mathrm{CaCl}_{2}+0.1 \mathrm{M}$ TEA and $0.005 \mathrm{M}$ DTPA + $1 \mathrm{M} \mathrm{NH} \mathrm{NCO}_{3}$ can be recommended in the determination of available Fe content of Trakya region calcareous soils because of the highest correlation coefficients (r) determined. On the other hand, these methods are suitable to certain physical and chemical properties of calcareous soils in this region. Results obtained can be applied to calcareous soils for available Fe content.

\section{Acknowledgement}

The abstract of this paper has been presented at the national conference "Turkey Natural Nutrition and Healthy Living 2015".

\section{References}

Adiloğlu A. 2006. Determination of suitable chemical extraction methods for the available iron content of Brown Forest Soils in Turkey. Eurasian Soil Science, 39: 961- 967.

Adiloğlu A. 2012. Türkiye tarımı ve geleceği paneli, NKÜ Ziraat Fakültesi’nin 30. Kuruluş Y1lı Etkinlikleri, 15 Mayıs, Tekirdağ.

Aydemir O. 1981. Comparison of various chemical extraction methods in predicting plant available soil iron. Turk. J. of Doğa, 5: 213- 220.

Başar H, Özgümüş A. 1999. Effects of various iron fertilizers and rates on some micronutrients contents of peach trees. Turk. J. Agric. Forest., 23 (3): 273- 281.

Chatzistathis T, Alifragis D, Therios I, Dimassi K. 2014. Comparison of three micronutrient soil test extractants in three Greece soil types. Commun. in Soil Science and Plant Analysis, 45: 381- 391.

Düzgüneş O, Kesici T, Kavuncu O, Gürbüz F. 1987. Araştırma ve deneme metodları (İstatistik metodları II). Ankara Üniversitesi, Ziraat Fak. Yay. No: 1021.

Eyüpoğlu F, Kurucu N, Talaz S. 1998. Türkiye topraklarının bitkilere yarayışlı mikro element ( $\mathrm{Fe}, \mathrm{Cu}, \mathrm{Zn}, \mathrm{Mn})$ durumu. Toprak, Gübre Araştırma Enst. Yayınları No: 72.

Gee GW, Bauder JW. 1986. Particle size analysis. In Methods of soil analysis, Part 1. Physical and mineralogical methods, Agronomy Monograph, No. 9, pp. 383-411.
Haddad KS, Evans JC. 1993. Assessment of chemical methods for extracting zinc, manganese, copper, and iron from New South Wales Soils. Commun. Soil Sci. Plant Anal., 24: 29- 44.

Jackson ML. 1967. Soil chemical analysis handbook. Micro-Macro Publishing, Inc, USA.

Johnson GVP, Young RA. 1973. Evaluation of EDDHA as an extraction and analytical reagent for assessing the iron status of soils. Soil Sci. 115: 11-17.

Kacar B, İnal A. 2010. Bitki Analizleri. Nobel Yayın No: 1241.

Krzysztof G, Zofia S, Urszula P, Krzysztof B. 2015. Suitability of different extractants for determination of available $\mathrm{Cu}$ and $\mathrm{Mn}$ Contents in Polish soils. Commoun. in Soil Science and Plant Analysis, 46 (S1): 81- 93.

Lindsay WL, Norvell WA. 1978. Development of a DTPA soil test for zinc, iron, manganese, and copper, Soil Sci. Am. J., 42: $421-428$.

Lindsay WL, Schwab AP. 1982. The Chemistry of iron in soils and its availability to plants. J. Plant Nutr., 5: 821-840.

Loeppert RH, Iskeep WP. 1996. Iron. Methods of soil analysis: Part 3. Chemical methods, Ed. by D. N. Sparks et al., SSSA Book Series, No. 5, pp. 639-664, Madison.

Loeppert RH, Suarez DL. 1996. Carbonate and gypsium. In D. L. Sparks et al. (ed.). Methods of soil analysis, Part 3, Chemical methods, SSSA Book series no: 5, p: 437-474, SSSA and ASA, Madison.

Martens DC, Westermann DT. 1991. Fertilizer applications for correcting micronutrient deficiencies. Micronutrients in Agriculture, $2^{\text {nd }}$ ed., SSSA Book Series, No. 4, Madison.

Mehlich A. 1984. Mehlich 3 soil test extractant: A Modification of Mehlich 2 extractant. Commun. in Soil Science and Plant Analysis, 15: 1409- 1416.

Nelson DW, Sommers LE. 1996. Total Carbon, organic carbon and organic matter. Methods of soil analysis: Part 3. Chemical methods, Ed. by D.L. Sparks et al., SSSA Book Series, No. 5, pp. 961-1010, Madison.

Olson RV. 1948. Iron solubility in soils asa by $\mathrm{pH}$ and free iron oxide content. Soil Sci. Soc. Am. Proc., 12: 153-157.

Sobral, L.F., Smyth, J.T., Fageria, N.K. and Stone, L.F. (2013). Comparison of copper, manganese and zinc extraction with Mehlich 1, Mehlich 3 and DTPA solutions for soils of the Brazilian Coastal Tablelands. Commun. in Soil Sci. and Plant Anal., 44: 2507- 2513.

Soltanpur PN. 1991. Determination of nutrient availability and elemental toxicity by AB-DTPA soil test and ICP-OES. Adv. Soil Sci., 16: 165-190.

Thomas GW. 1996. Soil pH and soil acidity. In D.L. Sparks et al. (ed.). Methods of soil analysis, Part 3, Chemical methods, SSSA Book series no: 5, p: 475-490, SSSA and ASA, Madison.

Yinanç A, Adiloğlu S. 2017. Use of plants in water treatment: models and pilot study case in Kozan district. Journal of Tekirdağ Agricultural Faculty, 14 (1): 114- 124.

Wear JI, Evans CE. 1968. Relationship of zinc uptake by corn and sorghum to soil zinc measured by three extractions. Soil Sci. Soc. Am. Proc., 32: 543-546. 